\title{
PELAKSANAAN PENERBITAN AKTA KEMATIAN DI DINAS KEPENDUDUKAN DAN PENCATATAN SIPIL KABUPATEN GORONTALO UTARA
}

\author{
Andi Yusuf Katili \\ STIA Bina Taruna Gorontalo \\ yusuf2801@gmail.com
}

\begin{abstract}
ABSTRAK
Tujuan penelitian ini untuk mengetahui Pelaksanaan Penerbitan Akta Kematian Di Dinas Kependudukan Dan Pencatatan Sipil Kabupaten Gorontalo Utara. Penelitian ini menggunakan jenis deskriptif pendekatan kualitatif.pengumpulan data dilakukan melalui observasi dan wawancara menggunakan pedoman wawancara yang diajukan kepada sejumlah informan. Tehknik analisis data menggunakan tehnik analisis dalam bentuk kata-kata lisan maupun tulisan.

Berdasarkan analisis hasil penelitian, maka dapat ditarik kesimpulan sebagai berikut : 1. Pelaksanaan Penerbitan Akta Kematian Di Dinas Kependudukan Dan Pencatatan Sipil Kabupaten Gorontalo Utara belum optimal disebabkan kurangnya tingkat kesadaran masyarakat untuk memiliki akta kematian. 2 Pelaksanaan Penerbitan Akta Kematian Di Dinas Kependudukan Dan Pencatatan Sipil Kabupaten Gorontalo Utara dilihat dari kelengkapan berkas yang disediakan oleh masyarakat tidak efesien selama melakukan proses pengurusan akta kematian yang dapat menghambat proses penerbitan akta kematian 3. Pelaksanaan Penerbitan Akta Kematian Di Dinas Kependudukan Dan Pencatatan Sipil Kabupaten Gorontalo Utara dari segi koordinasi kurang terjalin antara pemerintah desa dengan Dinas Kependudukan Dan Pencatatan Sipil Kabupaten Gorontalo Utara sehingga memberikan kerugian pada masyarakat akan ketentuan persyaratan yang berlaku sebagai prosedur penerbitan akta kematian.

Disarankan. 1 Perlunya Sosialisasi secara berkelanjutan yang dilakukan oleh pemerintah desa mengenai prosedur pengurusan akta kematian. 2 Perlunya kelengkapan berkas yang menjadi persyaratan untuk penerbitan akta kematian. 3 Perlu menjalin Koordinasi antara pemerintah desa dengan pemerintah daerah untuk mengikuti perkembangan persayaratan kelengkapan berkas dalam penerbitan akta kematian.
\end{abstract}

\section{Kata Kunci: Pelaksanaan, Penerbitan Akta Kematian}

\section{PENDAHULUAN}

Dalam kehidupan manusia akan terjadi suatu siklus hidup dimana manusia akan mengalami berbagai peristiwa penting di dalam hidupnya. Siklus hidup, pengalaman dan peristiwa penting tersebut diantaranya adalah kematian, dan berbagai peristiwa penting lainnya. Peristiwa-peristiwa penting tersebut perlu dilakukan pencatatan karena sangat mempengaruhi pengalaman hidup setiap manusia dan apabila peristiwa itu terjadi pasti akan selalu 
membawa akibat hukum bagi orang yang bersangkutan maupun bagi masyarakat di sekitarnya.

Mengingat begitu pentingnya peristiwa-peristiwa tersebut, maka demi terciptanya keadaan masyarakat yang tertib dan teratur serta demi terjaminnya kepastian hukum, maka diperlukan suatu peraturan untuk mengaturnya. Peraturan yang dimaksud tersebut adalah peraturan dibidang pencatatan sipil yang dilaksanakan oleh lembaga pencatatan sipil yaitu Kantor Catatan Sipil. Pencatatan sipil merupakan hak dari setiap warga negara dalam arti hak memperoleh akta autentik dari pejabat negara. Masih jarang penduduk menyadari betapa pentingnya sebuah akta bagi dirinya dalam menopang hidupnya. Misalnya manusia yang mengalami musibah kematian tentu memerlukan suatu keabsahan dalam tatanan suatu wilayah yang memberikan keluarga dari orang yang ditinggalkan akibat kematian memiliki identitas dari hal kematian,.

Sebuah akta kematian yang diterbitkan oleh pejabat Kantor Catatan Sipil, memiliki arti yang sangat besar di kemudian hari, manakala terjadi sesuatu. Misalnya untuk kepentingan menentukan ahli waris dari keluarga yang tinggalkan, atau dapat memberi arah ke pengadilan secara otentik dari dasar hukum yang berlaku di indonesia. Bahwa untuk dapat dijadikan dasar kepastian hukum seseorang maka data atau catatan peristiwa penting seseorang, seperti: kematian, perlu didaftarkan ke Kantor Catatan Sipil, oleh karena Kantor Catatan Sipil adalah suatu lembaga resmi
Pemerintah yang menangani hal-hal seperti di atas, Akta Kematian memiliki peranan penting dalam Akta Catatan Sipil sebagai Akta autentik yang memuat catatan lengkap seseorang yang dapat memberikan kepastian hukum pada peristiwa-peristiwa kematian bagi umat manusia.

Masyarakat yang ada di Kabupaten Gorontalo Utara dalam mengalami peristiwa kematian maka keluarga dari yang meninggal ini dapat memiliki Akta Kematian sebagai kepentingan ahli waris dalam hal yang bersangkutan dapat membuktikan sebagai bukti kematian yang sah didalam penegahkan hukum. Sangsi Administratif dan denda Bagi masyarakat yang lalai atau tidak melaporkan kepada Dinas Kepedudukan dan Catatan Sipil Kabupaten Gorontalo Utara selambat-lambatnya tiga puluh hari setelah peristiwa kematian, akan dikenakan sangsi berupa denda administrasi paling banyak satu juta rupiah. Dasar Pasal 90 Ayat (2) Undang-Undang Nomor 23 Tahun 2006 mengatakan setiap penduduk dikenai sangsi Administratif berupa denda apabila melampaui batas waktu pelaporan peristiwa penting.

Untuk mempermudah proses penerbitan akta kematian bagi masyarakat yang ada di Kabupaten Gorontalo Utara maka di butuhkan sebuah upaya dari dinas yang menerbitkan akta kematian yakni Dinas Kependudukan Catatan Sipil Kabupaten Gorontalo Utara dengan memberikan pemahaman kepada masyarakat sehingga mereka akan mengetahui manfaat dari akta kematian bagi ahli waris. 


\begin{abstract}
Namun demikian kenyataan yang ada tampaknya dari pelaksanaan penerbitan akta kematian ditemukan belum maksimal dapat dilihat dari: Sosialisasi yang dilakukan oleh pemerintah desa belum optimal dalam memberikan informasi kepada masyarakat yang nantinya selama melakukan pengurusan administrasi penerbitan akta kematian memenuhi prosedur pengurusan administrasi seperti kelengkapan kartu keluarga, surat kematian dari desa, KTP, atau data ahli waris, masih Kurangnya kelengkapan Berkas yang disediakan oleh masyarakat dalam hal menyiapkan persyaratan yang harus di lengkapi sesuai prosedur disaat melakukan pengurusan akta kematian di dinas catatan sipil, Masih Kurangnya koordinasi pemerintah desa dengan Dinas Kependudukan Catatan Sipil untuk kebutuhan singkronisasi data mulai dari penulisan nama dalam kartu keluarga yang sering tidak sesuai dengan data yang tercatat di dinas catatan sipil untuk memberikan capaian verifikasi data akurat dalam pelaksanaan penerbitan akta kematian.
\end{abstract}

\section{PERMASALAHAN}

Dari uraian latar belakang masalah yang telah dipaparkan tersebut, maka rumusan masalah dalam penelitian ini adalah bagaimana Pelaksanaan Penerbitan Akta Kematian Di Dinas Kependudukan Dan Pencatatan Sipil Kabupaten Gorontalo Utara?

\section{TUJUAN DAN MANFAAT PENELITIAN}

\section{Tujuan Penelitian}

Penelitian ini bertujuan untuk mengetahui Pelaksanaan Penerbitan Akta Kematian Di Dinas Kependudukan Dan Pencatatan Sipil Kabupaten Gorontalo Utara.

\section{Manfaat Penelitian}

Hasil penelitian ini diharapkan dapat memberikan banyak manfaat kepada semua pihak yang berkepentingan terutama kepada pihak Dinas Kependudukan Dan Pencatatan Sipil Kabupaten Gorontalo Utara. Dan dapat dijadikan sebagai referensi bagi pihak yang ingin melakukan penelitian yang sejenis.

\section{METODE PENELITIAN}

Jenis penelitian ini adalah penelitian deskriptif yang di lakukan dengan menggunakan metode kualitatif. Menurut Sugiyono (2010: 62) penelitian deskripitif adalah penelitian yang dilakukan terhadap satu variabel atau lebih, dimana prosedur penelitian deskriptif menghasilkan data deskriptif berupa kata tertulis atau lisan dari orangorang dan perilaku yang diamati. Sedangkan pendekatan metode kualitatif adalah jenis penelitian berdasarkan pendekatan penelitian dilakukan pada kondusif obyek yang alami, dimana peneliti sebagai instrumen utamanya / instrumen kunci, tehnik pengumpulan data dilakukan secara gabungan dan menghasilkan data deskriptif (Wiratha, 2008:54) sedangkan 
Husein Umar (2007:87), menyatakan sebagai berikut: "Penelitian deskriftif meliputi kegiatan pengumpulan data untuk menjawab pertanyaan mengenai status terakhir dari subyek penelitian. Tipe yang paling umum dari penelitian deskriptif meliputi penilaian terhadap individu, organisasi atau keadaan tertentu".

\section{Fokus Penelitian}

Penelitian ini difokuskan pada Dinas Kependudukan Dan Pencatatan Sipil Kabupaten Gorontalo Utara. yang dilakukan melalui 3 (tiga) aspek yaitu aspek Sosialisasi, Kelengkapan Berkas, Koordinasi, sebagai berikut:

\section{Sosialisasi}

Sosialisasi yang dimaksud dalam penelitian ini adalah sosialisasi yang dilakukan oleh pemerintah desa untuk memberikan tingkat kesadaran masyarakat dalam melakukan pengurusan administrasi penerbitan akta kematian yang sesuai prosedur pengurusan administrasi seperti kelengkapan kartu keluarga, surat kematian dari desa, KTP, atau data ahli waris.

\section{Kelengkapan Berkas}

Kelengkapan berkas yang dimaksud dalam penelitian ini adalah kelengkapan Berkas yang disediakan oleh masyarakat dalam hal menyiapkan persyaratan mulai dari kartu keluarga, ahli waris sampai dengan surat kematian sesuai prosedur disaat melakukan pengurusan akta kematian di dinas catatan sipil.

\section{Koordinasi}

Koordinasi yang dimaksud dalam penelitian ini adalah koordinasi pemerintah desa dengan pemerintah

daerah untuk kebutuhan

singkronisasi data yang dapat memberikan ferivikasi data akurat sehingga memudahkan pelaksanaan penerbitan akta kematian.

\section{HASIL PENELITIAN DAN PEMBAHASAN}

\section{Sosialisasi}

Sosialisasi merupakan tahapan dalam memberikan pemahaman masyarakat dalam melakukan pengurusan akta kematian yang bertujuan untuk mencapai fungsi tertib administrasi melalui tata cara dan mekanisme pengurusan akta kematian secara efektif. Terkait dengan sosialisasi tersebut maka pemahaman masyarakat mengenai fungsi akta kematian itu dapat berhubungan erat dengan status hukum seseorang, baik hukum privat maupun publik. Bahkan, akta kematian akan menjadi salah satu prasyarat penting bagi kepengurusan dokumen lain disebabkan Manfaat dari akta kematian bagi ahli waris diantaranya untuk mengurus penetapan ahli waris, pensiunan, klaim asuransi, maupun persyaratan perkawinan bagi duda atau janda dengan kata lain dalam waktu 14 hari sejak didaftarkan, akte kematian sudah bisa keluar. yang berdasarkan Undang-undang No 23 tahun 2006 tentang Administrasi Kependudukan, pelaporan permohonan akte kematian paling lama 30 hari sejak kematian.

Hasil penelitian menunjukkan bahwa pada prinsipnya sosialisasi dilakukan melalui tingkat desa yang dapat mewujudkan kesadaran masyarakat kenyataan yang ada masih banyak masyarakat yang 
belum paham akan prosedur pengurusan akta kematian yang sesuai dengan persyaratan untuk penerbitan dokumen akta kematian sehingga masih seringkali berkas yang dimasukkan tidak sesuai prosedur sebagai acuan penyelesaian dokumen akta kematian pada saat itu juga, masih ada masyarakat yang belum paham atau belum memiliki kesadaran dalam melakukan pengurusan akta kematian dimana sebagian besar warga yang tidak melaporkan peristiwa kematian adalah warga masyarakat yang dari segi ekonominya tergolong miskin dan tidak mengetahui manfaat akta kematian serta sebagian enggan untuk mengurusnya, masih ada sebagian masyarakat yang belum mengetahui manfaat dari pada akta kematian yang nantinya sebagai bukti sah mengenai status kematian seseorang, terdapat tingkat kesadaran masyarakat yang masih sangat kurang sehingga menyebabkan minat masyarakat melakukan pengurusan akta kematian sampai di tingkat desa yang tidak memiliki kemauan untuk melakukan pengurusan di tingkat kabupaten yang dapat menerbitkan akta kematian.

\section{Kelengkapan Berkas}

Kelengkapan Berkas merupakan indikator yang penting dalam melakukan pengurusan penerbitan akta kematian yang di jadikan sebagai panduan pelaksanaan akta kematian di Dinas Kependudukan Dan Pencatatan Sipil Kabupaten Gorontalo Utara sebagai kebutuhan administrasi yang harus di penuhi oleh masyarakat selama melakukan proses penerbitan akta kematian.

Hasil penelitian menunjukkan bahwa kelengkapan berkas selama melakukan pengurusan administrasi penerbitan akta kematian sesuai prosedur belum maksimal di akibatkan oleh masih banyak masyarakat yang belum paham akan prosedur pengurusan akta kematian yang sesuai dengan persyaratan untuk penerbitan dokumen akta kematian sehingga masih seringkali berkas yang dimasukkan tidak sesuai prosedur sebagai acuan penyelesaian dokumen akta kematian pada saat itu juga, masih ada masyarakat yang belum paham atau belum memberikan sesuai prosedur yang mengakibatkan keterlambatan penerbitan akta kematian salah satu contoh masyarakat sebagai pemohon tidak menyiapkan dokumen ahli waris atau kartu tanda penduduk yang terdaftar dalam kartu keluarga, prasyarat kelengkapan berkas dalam penerbitan akta kematian memudahkan masyarakat selama proses penerbitan kata kematian menunjukkan hasil yang berbeda di tingkat desa dengan prasayarat di tingkat kabupaten sehingga berkas tersebut yang disediakan oleh masyarakat belum dapat diproses tepat wakt, kurangnya tingkat kesadaran masyarakat melakukan pengurusan akta kematian tidak melalui tahapan di tingkat desa yang harus menyiapkan surat pengantar kematian dari pemerintah desa di 
akibatkan oleh kemauan masyarakat melakukan pengurusan secara cepat tanpa melalui prosedur untuk memenuhi pengurusan dana santunan duka yang diberikan batas waktu yang justru memberikan keterlambatan proses penerbitan akta kematian.

\section{Koordinasi}

Koordonasi adalah sebuah kegiatan yang saling berkesinambungan antara pemerintah desa dengan pemerintah daerah dalam hal ini dinas kependudukan dan pencatatan sipil untuk pelaksanaan penerbitan akta kematian di Dinas Kependudukan Dan Pencatatan Sipil Kabupaten Gorontalo Utara sehingga mewujudkan kebutuhan singkronisasi data yang dapat memberikan ferivikasi data akurat yang memudahkan pelaksanaan penerbitan akta kematian.

Hasil penelitian menunjukkan bahwa koordinasi yang terjalin antara pemerintah desa dengan pemerintah daerah masih sangat kurang di akibatkan kurang kepedulian pemerintah desa dalam melakukan koordinasi dengan Dinas Kependudukan Dan Pencatatan Sipil yang mengakibatkan tumpang tindih aturan yang telah di tetapkan yang mengakibatkan kerugian waktu dalam melakukan pengurusan akta kematian oleh masyarakat

\section{SIMPULAN}

Berdasarkan hasil penelitian dan pembahasan di atas, maka peneliti dapat menarik kesimpulan sebagai berikut:

1. Belum optimalnya sosialisasi yang dilakukan oleh pemerintah desa mengenai manfaat kepemilikan akta kematian sehingga tidak mewujudkan tingkat kesadaran masyarakat untuk memiliki akta kematian.

2. Masih kurangnya kelengkapan berkas yang disediakan oleh masyarakat selama melakukan proses pengurusan akta kematian sehingga dapat menghambat proses penerbitan akta kematian.

3. Masih kurang terjalin koordinasi pemerintah desa dengan Dinas Kependudukan Dan Pencatatan Sipil Kabupaten Gorontalo Utara sehingga memberikan kerugian pada masyarakat akan ketentuan persyaratan yang berlaku sebagai prosedur penerbitan akta kematian.

4. Masih kurangnya Sosialisasi, kelengkapan berkas, koordinasi dalam memenuhi prosedur yang menyebabkan penerbitan akta kematian belum optimal.

\section{SARAN}

Berdasarkan kesimpulan tersebut, maka peneliti dapat menyarankan sebagai berikut:

1. Perlunya Sosialisasi secara berkelanjutan yang dilakukan oleh pemerintah desa mengenai prosedur pengurusan akta kematian.

2. Perlunya kelengkapan berkas yang menjadi persyaratan untuk penerbitan akta kematian.

3. Perlu menjalin Koordinasi antara pemerintah desa dengan 


\begin{tabular}{lrr} 
pemerintah & daerah untuk \\
mengikuti & perkembangan \\
persayaratan & kelengkapan & berkas \\
dalam penerbitan akta kematian. \\
Perlunya & Sosialisasi, kelengkapan \\
berkas, koordinasi & dalam \\
memenuhi & prosedur & untuk \\
memberikan & \multicolumn{2}{c}{ optimalisasi } \\
penerbitan akta kematian
\end{tabular}

\section{DAFTAR PUSTAKA}

Abdul Wahab, Solichin. 2008. Analisis Kebijaksaan Dari Formulasi Ke Implementasi Kebijaksanaan Negara. Jakarta: Bumi Aksara.

Abidin, Z.S. 2010. Kebijakan Publik. Jakarta: Yayasan Pancur Siwah.

Anderson, James E. 2008. Public Policy Making: An Introduction. Boston: Houghton Mifflin Company

Bernadine R. Wirjana, M.S.W dan Prof. Dr. Susilo Supardo. 2009. Kepemimpinan, Dasar-Dasar dan Pengembangannya. Yogyakarta: CV. Andi offset.

Bernardin \& Russel. 2007. Pinter Manajer, Aneka Pandangan Kontemporer. Alih Bahasa Agus Maulana. Jakarta: Penerbit Binarupa Aksara..

Boediono 2009 Teori Pertumbuhan Ekonomi. Yogyakarta: BPFE Yogyakarta

Dunn, William N. 2007. Analisis Kebijakan Publik. Yogyakarta: Gadjah Mada University Press. Effendy, Onong Uchjana. 2007. Ilmu, Teori dan Filsafat Komunikasi. Bandung: Citra Aditya Bakti.
Fayol, Henry. 2009. General Principles of Management, Classics of Organization Theory. California: Brooks/Cole Publishing Company Pacific Grove.

Friedrich, Carl J, Man and His Government. 2009. New York: McGraw-Hill.

Gaspersz, Vincent. 2010. Sistem Manajemen Kinerja

Terintegrasi Balanced

Scorecard dengan Malcolm Baldrige dan Lean Six Sigma Supply Chain Management. Jakarta: PT Gramedia Pustaka Utama

Husein, Umar. 2008. Metode Penelitian Untuk Skripsi dan Tesis Bisnis. Jakarta. PT Rajagrafindo Persada

I Made Wirartha. 2008. Metodologi Penetilian Sosial Ekonomi. Yogyakarta: C.V Andi Offset.

Keban, Yeremias T. 2008. Enam Dimensi Strategis Administrasi Publik: Konsep, Teori, dan Isu. Edisi Kedua. Cetakan Pertama. Yogyakarta: Penerbit Gaya Media.

Mochtar R. 2012. Sinopsis Obstetric Fisiologi dan Patologi. Jilid 1. Jakarta: Penerbit buku kedokteran EGC

Pasolong, Harbani. 2008. Kepemimpinan Birokrasi, Bandung: CV Alfabeta

Sinambela, Lijan Poltak. 2007. Reformasi Pelayanan Publik:Teori, Kebijakan, dan Implementasi. Jakarta: PT. BumiAksara.

Soesilo Zauhar. 2007. Reformasi Administrasi Konsep, Dimensi, 


\section{dan Strategi. Jakarta: Bumi}

Aksara

Subarsono, AG. 2011. Analisis

kebijakan Publik: Konsep.

Teori dan Aplikasi.

Yogyakarta: Pustaka Pelajar.

Sugiyono. 2010. Metode Penelitian

Kuantitatif Kualitatif dan

$R \& D$. Bandung: Alfabeta.

Syafiie, Inu Kencana. 2007.

Kepemimpinan Pemerintahan

Indonesia. Bandung: Refika

Aditama 